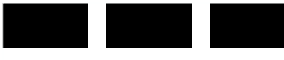 \\ m \\ THE WiLliam DAVIDSON INSTITUTE \\ AT THE UNIVERSITY OF MICHIGAN BUSINESS SCHOOL
}

\section{Official Foreign Exchange Interventions in the Czech Republic: Did They Matter?}

\author{
By: Balázs Égert and Luboš Komárek
}

William Davidson Institute Working Paper Number 760

March 2005 


\title{
Official Foreign Exchange Interventions in the Czech Republic: Did They Matter?
}

\author{
Balázs Égert*
}

\author{
Luboš Komárek
}

\begin{abstract}
This paper studies the impact of daily official foreign exchange interventions on the Czech koruna's exchange rate vis-à-vis the euro (German mark prior to 1999) from 1997 to 2002. Using both the event study methodology and a variety of GARCH models reveal that central bank interventions, especially koruna purchases were fairly ineffective from 1997 to mid-1998 compared to the size of the interventions. However, from mid-1998 to 2002, koruna sales were surprisingly effective in either smoothing the path of the exchange rate or even reversing the appreciating trend up to 60 days. Higher volatility triggered koruna purchases in the period from 1997 to mid-1998, which in turn leads to higher volatility. This suggests that the CNB tried in vain to calm the markets after the currency crisis. Koruna sales simply yield more forex rate volatility, a by-product of the monetary authorities' efforts to counter excessive appreciation.
\end{abstract}

JEL Codes: F31

Keywords: central bank intervention, foreign exchange intervention, transition economies

\footnotetext{
1* Oesterreichische Nationalbank; MODEM, University of Paris X-Nanterre and William Davidson Institute. E-mail: balazs.egert@oenb.at and begert@u-paris10.fr

- Czech National Bank and Prague School of Economics, E-mail: lubos.komarek@.cnb.cz and luboskomarek@yahoo.com

Many thanks go to Jan Babetskii, Tomas Kvapil, Jan Frait, Christoph Fischer and Zoltán Walko for help in obtainining some of the data series used in the paper. The opinions expressed in the paper are those of the authors and do not necessarily represent the views of the Czech National Bank, the Oesterreichische Nationalbank or the European System of Central Banks (ESCB).
} 


\section{Introduction}

Although it is widely acknowledged that unsterilised interventions may well have an influence on the exchange rate through changes in relative money supplies, for industrialised OECD economies, the empirical evidence is fairly mixed regarding the effectiveness of sterilised interventions, which may work through the portfolio, the signalling and the microstructure (or co-ordination) channels. For instance, Aguilar and Nydahl (2000) found limited effectiveness of official interventions for Sweden. Morana and Beltratti (2000) report similar results for the USD/DM exchange rate and Brandner et al. (2001), Brandner and Grech (2002) for the ERM currencies. Brissimis and Chionis (2004) suggest that interventions by the ECB were not effective for the yen/euro exchange rate. In contrast with these findings stand Fatum (2000), who finds evidence for effectiveness for the same currency pair. Ramaswamy and Samiei (2000), Fatum and Hutchison (2003) and Brissimis and Chionis (2004) show that sterilised interventions were effective for the yen/USD and yen/euro exchange rates. Finally, Kim et al (2000), Edison et al. (2003) and Rogers and Siklos (2003) report mixed evidence for the case of Australia. None the less, Sarno and Taylor (2001) conclude in their literature survey that official interventions may succeed in influencing the exchange rate in the event that interventions are well communicated and are in line with the fundamentals.

Canales-Kirjenko (2003) has recently argued that foreign exchange interventions may be more effective in developing and transition economies than in well-established industrialised countries because official interventions may work better in foreign exchange markets with low turnover, and because the market organisation and the regulatory framework may be more conducive to interventions, and moral suasion may also play a bigger role. Nevertheless, there is astonishingly little empirical research conducted to confirm the hypothesis of the effectiveness of central bank interventions in developing and emerging market economies ${ }^{2}$ and no study has been so far published for transition economies using daily intervention data. ${ }^{3}$

In this paper, daily intervention data are used to study whether foreign exchange interventions were effective in the Czech Republic from 1997 to 2002. We first apply the event study approach and then employ a range of GARCH models to analyse the influence of official interventions on

\footnotetext{
${ }^{2}$ Domac and Mendoza (2002) and Guiamaraes and Karacadog (2004) studied the cases of Turkey and Mexico.

${ }^{3}$ Holub (2004) analysed, in a narrative way, the case of the Czech Republic using monthly data.
} 
the mean and the variance of the koruna's exchange rate vis-à-vis the German mark prior to 1999 and the euro after 1999.

The rest of the paper is structured as follows. Section 2 describes briefly exchange rate and monetary policies and foreign exchange interventions in the Czech Republic. Section 3 presents the results of the event study approach. Section 4 contains the estimation results of the different GARCH specifications. Section 5 finally gives some concluding remarks.

\section{The Role of Foreign Exchange Interventions in the Czech Republic}

Similarly to other transition economies of Central and Eastern Europe, monetary policy in Czechoslovakia and, after its split-up in 1993, in the Czech Republic was relying, at the early stages of the transition process, on the exchange rate as an intermediate target to achieve price stability. After four rounds of devaluation against the currency basket in $1990^{4}$, the Czech(oslovakian) koruna's central parity in the pegged system remained unchanged until the introduction of the managed float regime as a consequence of the currency crisis in 1997. As a result, average yearly inflation as high as $56.6 \%$ in 1991 , chiefly as a consequence of price liberalisation, was brought down to $10 \%$ in 1994 and was stabilised in high one digit territory from 1995 to 1997.

The Czech Republic complied with Article VIII of the IMF from October 1, 1995 on and joined the OECD in December 1995. This not only implied a very extensive liberalisation of the capital accounts, but also opened the door to massive capital inflows, the consequence of which was that the extremely tight fluctuation band of below $\pm 1 \%{ }^{5}$ had to be widened to $\pm 7.5 \%$ on 28 February 1996. This was followed by the speculative attack against the Czech currency in May 1997, which, after massive interventions on the forex markets, pushed the Czech National Bank to

\footnotetext{
${ }^{4}$ January 2, 1990: 2.1\%; January 8, 1990: 16.3\%; October 15, 1990: 55.2\%; 28 December 1990: 15.9\%. The currency basket was composed of 32.88\% USD, $40.93 \%$ DM, $12.32 \%$ ATS, $4.82 \%$ FRF and $9.05 \%$ CHF until December 27, 1990. From December 28, 1990, weights in the basket were adjusted and the French franc was replaced by the British pound: $31.34 \%$ USD, $45.52 \%$ DM, $12.35 \%$ ATS, $4.24 \%$ GBP and $6.55 \%$ CHF. On January 2, 1992, weights were re-adjusted and the French franc regained its previous position by crowding out the British pound: $9.7 \%$ USD, 36.15\% DM, 8.07\% ATS, 2.92\% FRF and 3.79\% CHF. Shortly after the introduction of the Czech koruna, the basket was simplified to two currencies in May 3, 1993: 35\% USD and 65\% DM.

${ }^{5} \pm 0 \%$ till August 1992, $\pm 0.5 \%$ from September 27, 1992 to April 24 1995, $\pm 0.75 \%$ from April 251995 until February 27 (this widening was due to the fact that the CNB charged an additional 25 p.p. as a fee for trades on the market), 1996 and $\pm 7.5 \%$ from February 28, 1996 to May 26, 1997.
} 
abandon the peg and to introduce managed float on 27 May 1997. The new regime was oriented against the German mark and after 1998, against the euro (CNB, 1997, p. 25).

Figure 1. Exchange Rate Regime in the Czech Republic, 1993-2005

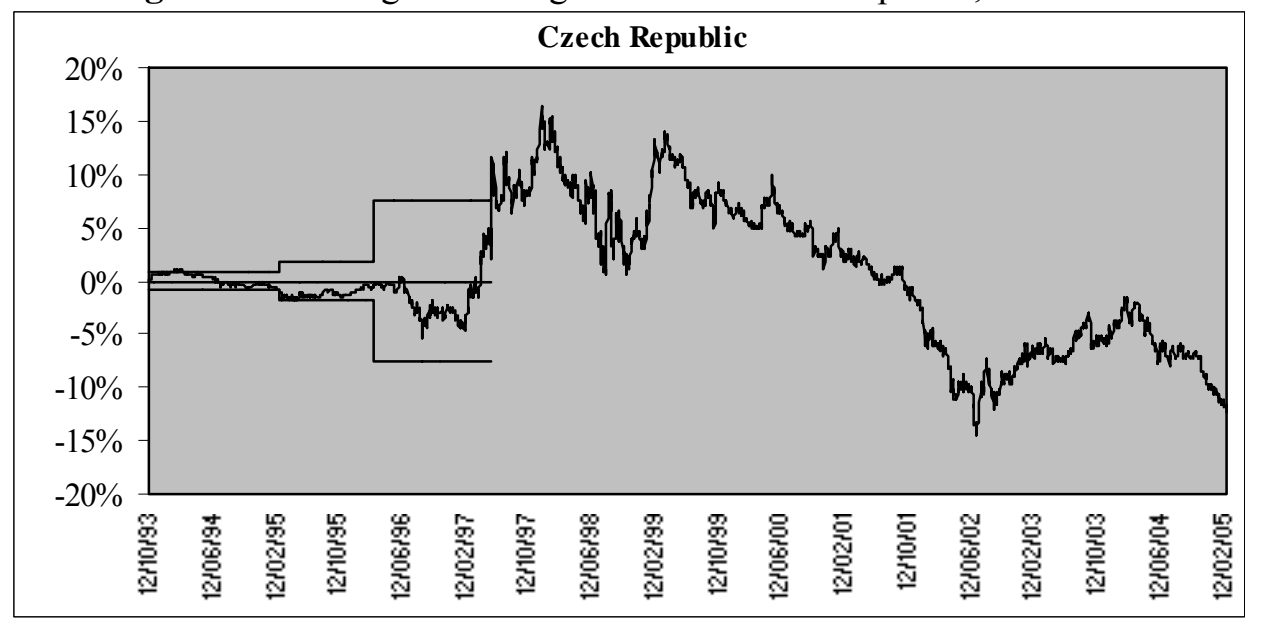

Note: Exchange rate developments are depicted relative to the official central parity prevailing in the pegged regime. The series refers to the koruna's exchange rate vis-à-vis the basket under the peg, and against the German mark and the euro in the managed float.

As the exchange rate could not serve anymore as an intermediate target, and because money demand was too unstable to serve as an anchor, the Czech National Bank introduced, first among the transition economies, a direct inflation targeting framework from the beginning of $1998 .^{6}$

In the framework of the inflation targeting policy, the Czech National Bank (CNB) preserves the right to intervene on the foreign exchange market if there are "major deviations of the exchange rate that are not connected with domestic economic fundamentals and domestic monetary policy (CNB, 1998, p. 46). A strong motivation for the CNB to avoid strong currency misalignments is the high openness of the Czech economy in terms of exports and imports. ${ }^{7}$

As shown on Figure 1, the koruna was on a steady appreciating path from 1998 till the end of 2002, brought about by the massive privatisation of the corporate sector and greenfield investments, which resulted in an inflow of around USD 30 billion $^{8}$ if FDI between 1998 and 2002. During this period, the CNB intervened on the foreign exchange markets in an attempt to smooth or event to reverse the appreciation of the koruna vis-à-vis the German mark and the

\footnotetext{
${ }^{6}$ For a very comprehensive treatment of inflation targeting in the Czech Republic, see Coats (2000).

${ }^{7}$ The ration $((\mathrm{X}+\mathrm{M}) / 2) / \mathrm{GDP}$ was around $50 \%$ in 1997 and increase to about $60 \%$ by 2000 and to approximately $56 \%$ at the end of 2002 .

${ }^{8}$ billion $=10^{9}$
} 
euro. ${ }^{9}$ From 2000 to 2002, off-market operations concerted between the CNB, the Ministry of Finance and the National Property Fund were also undertaken to neutralise the effects of privatisation revenues on the exchange rate (CNB, 2001, 2002).

Figure 2 and Table 1 provide an overview of the CNB's intervention activity on the foreign exchange markets, according to which the Czech central bank both sold and purchases the domestic currency in the aftermath of the currency crisis in 1997. Although it also purchased koruna in 1998 on a few occasions, from 1998 to late 2002, the Czech monetary authorities' interventions took the shape of koruna sales to smooth the appreciation or even to try to weaken of the Czech currency. Figure 3 also indicate that especially in 1997 and 1998, central bank interventions are associated with increased exchange rate volatility. Although our daily intervention series ends in 2002, it should be noted that the CNB did not intervene in 2003, but was buying the koruna from April 2004 onwards. These foreign currency sales can be viewed not that much as efforts to avoid excessive depreciation but rather as sales of foreign reserves motivated by the elimination of losses of the CNB (by appreciating the CZK).

Figure 2. Interventions in the Czech Republic

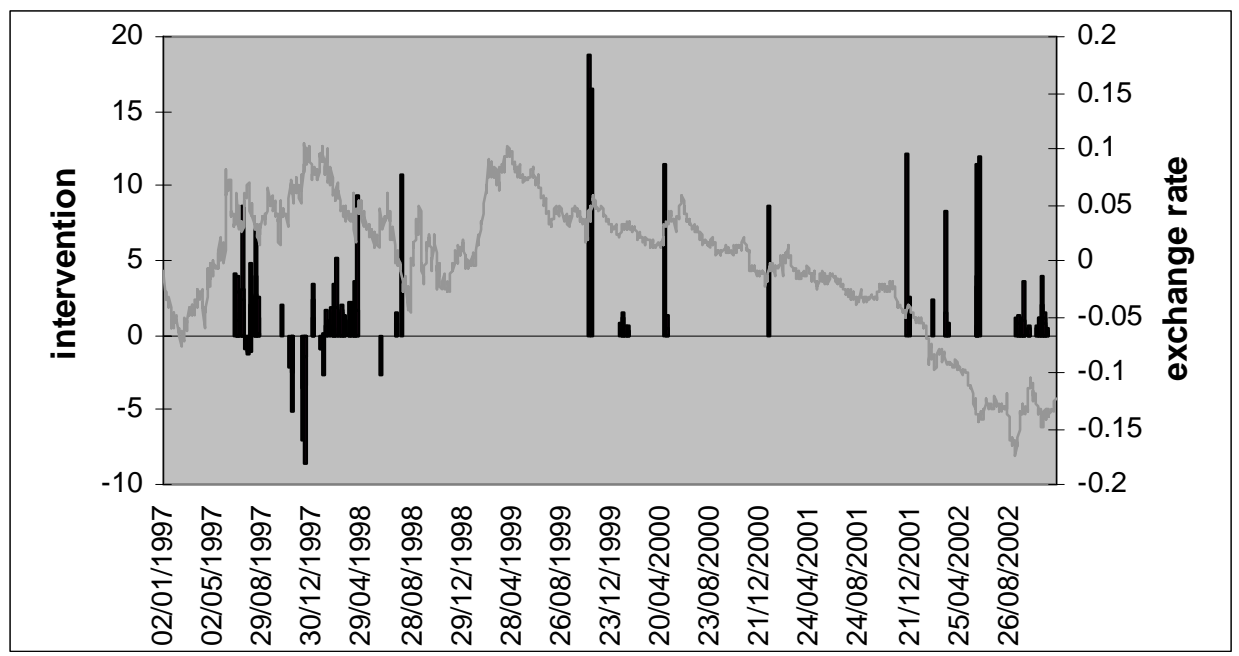

Source: Czech National Bank

Note: Interventions are in billions of Czech koruna. Negative (positive) values show koruna purchases (sales).The exchange rate is shown as the deviation from the period average koruna/euro (German mark) exchange rate.

${ }^{9}$ CNB (1998, p 33.): "The CNB intervened on the foreign exchange market to moderate the appreciation pressures generated by the foreign capital inflow."

CNB (1999, p 45.): "the koruna's exchange rate was affected by the CNB's interventions to prevent an excessive koruna appreciation."

CNB (2000, p. 48): “The koruna's nominal exchange rate against the euro exhibited an overall appreciation tendency in 2000. This gradual strengthening was interrupted at end-Q1 by the CNB's foreign exchange interventions to prevent excessive appreciation of the koruna..."

CNB (2002, p. 36): "The koruna continued to appreciate (...). As a result, at its extraordinary meeting on 21 January 2002 the Bank Board (...) also approved intervention in the foreign exchange market." 
Figure 3. Interventions and unconditional exchange rate volatility in the Czech Republic

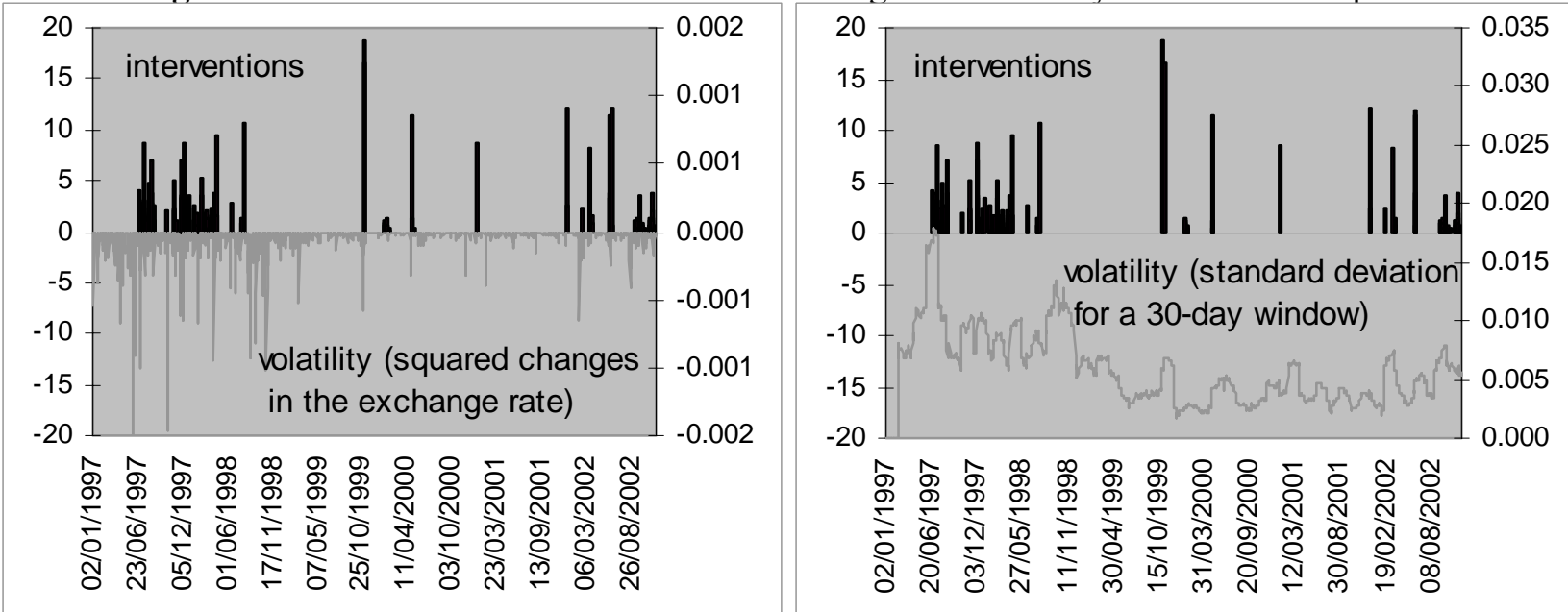

Note: Interventions are shown in absolute value. Volatility is measured as the mirror image of squared changes in the exchange rate $(\Delta e)^{2}$ in the figure on the left-hand side. In the figure on the right hand side, volatility is computed as standard deviation for a backward looking 30-day window.

Table 1. Summary of interventions activities of the Czech National Bank, 1997:06-2002

(CZK billions)

\begin{tabular}{|c|c|c|c|c|c|c|c|}
\hline & & Mean & Median & Min & $\operatorname{Max}$ & SD & Days of intervention \\
\hline \multirow[t]{3}{*}{1997} & Total & 2.88 & 2.42 & 0.18 & 8.69 & 2.03 & 40 \\
\hline & Sales & 2.81 & 2.52 & 0.18 & 8.59 & 1.82 & 27 \\
\hline & Purchases & 3.03 & 2.13 & 0.95 & 8.69 & 2.49 & 13 \\
\hline \multirow[t]{3}{*}{1998} & Total & 1.94 & 1.46 & 0.19 & 10.75 & 2.26 & 37 \\
\hline & Sales & 1.95 & 1.46 & 0.19 & 10.75 & 2.38 & 33 \\
\hline & Purchases & 1.84 & 1.83 & 0.99 & 2.72 & 0.99 & 4 \\
\hline \multirow[t]{3}{*}{1999} & Total & 4.10 & 0.81 & 0.22 & 18.76 & 7.16 & 10 \\
\hline & Sales & 4.10 & 0.81 & 0.22 & 18.76 & 7.16 & 10 \\
\hline & Purchases & 0.00 & 0.00 & 0.00 & 0.00 & 0.00 & 0 \\
\hline \multirow[t]{3}{*}{2000} & Total & 4.45 & 1.27 & 0.36 & 11.49 & 5.24 & 5 \\
\hline & Sales & 4.45 & 1.27 & 0.36 & 11.49 & 5.24 & 5 \\
\hline & Purchases & 0.00 & 0.00 & 0.00 & 0.00 & 0.00 & 0 \\
\hline \multirow[t]{3}{*}{2001} & Total & 5.64 & 2.52 & 2.33 & 12.08 & 5.57 & 3 \\
\hline & Sales & 5.64 & 2.52 & 2.33 & 12.08 & 5.57 & 3 \\
\hline & Purchases & 0.00 & 0.00 & 0.00 & 0.00 & 0.00 & 0 \\
\hline \multirow[t]{3}{*}{2002} & Total & 1.91 & 0.91 & 0.10 & 12.06 & 2.84 & 37 \\
\hline & Sales & 1.91 & 0.91 & 0.10 & 12.06 & 2.84 & 37 \\
\hline & Purchases & 0.00 & 0.00 & 0.00 & 0.00 & 0.00 & 0 \\
\hline \multirow[t]{3}{*}{$1997-2002$} & Total & 2.56 & 1.43 & 0.10 & 18.76 & 3.24 & 132 \\
\hline & Sales & 2.53 & 1.42 & 0.10 & 18.76 & 3.37 & 115 \\
\hline & Purchases & 2.75 & 2.13 & 0.95 & 8.69 & 2.26 & 17 \\
\hline
\end{tabular}




\section{The Event Study Approach}

\subsection{Methodological Considerations}

A big advantage of the event study approach over time series techniques is that it only looks at periods when interventions take place, and is thus able to filter out longer periods during which no interventions happen and which may cause econometric studies to find no relation between foreign exchange interventions and exchange rate behaviour (Fatum, 2000; Fatum and Hutchinson, 2003).

When applying the event study approach, three issues have to be tackled:

(a) how single interventions in one direction can form a single intervention episode or event:

the question is of how many days may separate two single intervention acts going in the same direction (both purchases or both sales) can be considered as two distinct intervention events. Five alternative definitions of the intervention event are considered in this study. We consider intervention events, which comprise single interventions in one direction between which up to 2 , 5, 10, 20 and 30 consecutive days can pass without intervention activity. The intervention event ends if more than $2,5,10,20$ or 30 days go by without intervention or if an intervention in the other direction takes place. ${ }^{10}$

(b) under what circumstances an intervention episode can be viewed as effective/successful:

Three classes of effective interventions can be distinguished.

Leaning against the wind (WIND): central bank interventions reverse the trend of the exchange rate, i.e. the exchange rate depreciates (appreciates) in the pre-event window, and following the purchases (sales) of domestic currency, it appreciates (depreciates) in the post-event window.

Smoothing exchange rate movements (SMOOTH): central bank interventions slow down the appreciation or the depreciation of the domestic currency, i.e. buying (selling) the domestic currency causes the exchange rate to depreciate less (appreciate more) in the post-event window than in the pre-event window.

\footnotetext{
${ }^{10}$ Fatum (2000) and Fatum and Hutchison (2003) use up to 15 days and Edison et al. (2003) use up to 10 days with no intervention between two neighbouring interventions within an event.
} 
Leaning with the wind (WITH): purchases (sales) of the domestic currency should cause the exchange rate to appreciate more (depreciate more) after the intervention episode than before the intervention episode.

(c) how long a time horizon should be analysed before and after the intervention event (definition of pre- and post-event windows)

As to the size of the pre- and post-event windows, we look at six different lengths: 2, 5, 10, 20, 30,40 and 60 . The pre- and post-event windows are constructed in a symmetric way implying that a 2-day (5-day etc.) pre-event window is compared to a 2-day (5-day etc.) post-event window. ${ }^{11}$ In addition, effectiveness is also analysed for the event window itself. The pre-event window is set to $2,5,10,20$ and 30 days if the event window size is equal or lower than 2 days (higher than $2(5,10,20$ and 30) but equal or lower than $5(10,20$ and 30)).

Finally, not only changes in the exchange rate but also changes in the volatility of the exchange rate can be analysed. For this purpose, volatility measured as standard deviation over the (symmetric) pre- and post-event windows are compared.

\subsection{Data and Results}

The source of daily foreign exchange intervention data is the Czech National Bank. The sample period spans from January 1997 to August 2002. The interventions are expressed in terms of domestic currency because the sample period comprises the switch from the German mark to the euro. Expressing interventions in the same currency units ensures full comparability. Note also that the Czech National Bank intervened in US dollar once in July 1997. As stated in CNB (1997), the managed float was, however, oriented to the German mark. In accordance with common practice in the literature, purchases (sales) of the foreign currency are positive (negative) values. Thus, purchases (sales) of the domestic currencies are denoted with negative (positive) figures. The exchange rate series against the German mark and the euro are provided by the Czech National Bank. Only data for trading days are considered for the study implying the exclusion of week-ends and public holidays.

\footnotetext{
${ }^{11}$ Fatum (2000) employs 2, 5, 10, and 15-day window sizes, whilst Edison et al. (2003) looks at 2-day and 21-day windows. Edison and others term the 2-day window the short-term and the 21-day window the long-term.
} 
As shown in Table 2, the number of intervention episodes in the Czech Republic varies between 29 (maximum 2 days of no intervention) and 18 (maximum 30 days of no intervention). The number of intervention episodes appears to be fairly robust to the use of the 10-day, 20-day and 30-day filters as the number of identified episodes are 21, 19 and 18, respectively.

Table 2. The number of the identified intervention episodes

\begin{tabular}{|c|r|c|c|c|}
\hline \multicolumn{5}{|c|}{$\begin{array}{r}\text { Maximum days of intervention inactivity between two } \\
\text { consecutive interventions }\end{array}$} \\
\hline \multicolumn{5}{|c|}{$1997: 06$ to 2002:09 } \\
\hline 2 days & 5 days & 10 days & 20 days & 30 days \\
\hline 29 & 23 & 21 & 19 & 18 \\
\hline
\end{tabular}

Table 3 reports results regarding the relationship between the exchange rate and exchange rate volatility on the one hand, and on the 18 intervention episodes established on the basis of the 30day no-intervention, on the other hand. In yellow are marked the pre- and post event windows without any overlap with previous or forthcoming intervention episodes. Note that detailed results for different event sizes are not reported hereafter ${ }^{12}$. However, summary statistics for events established using intervention inactivity between two consecutive interventions of 2, 5, 10 and 30 days are given in Tables 4 and 5.

As can be seen in Table 3, it is very difficult to assess the effectiveness of the intervention events in 1997 and early 1998, because of the overlaps between individual events. This seems to be no problem for the second half of the period. There are only four events consisting in koruna purchases, of which two (No. 5 and No. 9) are found to be completely ineffective, one (No. 7) cannot be evaluated at all because of overlaps, whilst the remaining one (No. 2) appears to be a leaning against the wind, i.e. reversing depreciation over a very short time period (2 days). Koruna sales during the same period are a little more effective, but only at very short time horizons. It should be mentioned, though, that there are a number of overlapping pre- and postwindow sizes, for which some of the intervention events qualify as either leaning against the wind or exchange rate smoothing. The difficulty of interpreting these results is, however, not only that they are in an overlapping window, but also because overlaps occur between domestic currency sales and purchases.

The second part of the period under study from mid-1998 to end-2002 covers only intervention episodes, which were all koruna sales. Not only that overlapping windows are less of a problem,

\footnotetext{
12 These results are available from the authors upon request.
} 
but these intervention events are strikingly effective in either smoothing or reverting the appreciation of the koruna. For pre- and post-event windows higher than 2 days, out of the forty three assessable windows, only two are found to be unsuccessful and for the rest success always imply either exchange rate smoothing or leaning against the wind strategies.

Table 4 documents that these results are not particularly sensitive to how the intervention events are defined (number of no intervention activity between two single intervention act). A general observation is that as the pre- and post event window size increases, the number of assessable periods drops significantly. However, when assessable, the share of successes amount to around $80 \%$ for pre- and post-event windows of 2, 5, 10 or 20 days and to a very impressive $100 \%$ for pre- and post-event windows of 30, 40 and 60 days. At the same time, for pre- and post-event windows higher than 2 days, successful periods are either exchange rate smoothing or leaning against the wind. The share of leaning against the wind episodes dominates exchange rate smoothing for short pre- and post-event window, the domination transforms into exchange rate smoothing. This indicates that it is easier to reverse the trend of the exchange rate in the short run than at 30-day or longer horizons.

Regarding unconditional exchange rate volatility measured by means of standard deviation, interventions are associated with both increases and decreases in volatility (Table 3 ). There are episodes for which whether or not volatility increases or decreases hinges largely upon the size of the pre- and post-event window. For a number of episodes especially in 1998 and 1999, interventions systematically cause exchange rate volatility to increase, while in 2001 and 2002, they tend to dampen forex volatility. Table 5 summarises these results in a more systematic way, and suggests that for short pre- and post-event windows, the share of intervention episodes for which forex volatility increased equals the one of episodes followed by lower forex volatility. However, in the longer term up to 60 days, foreign exchange interventions tend to be associated with a rise rather than with a drop in foreign exchange volatility. 
Table 3. The effectiveness of intervention episodes based on maximum 30 days of no intervention

\begin{tabular}{|c|c|c|c|c|c|c|c|c|c|c|c|c|c|c|}
\hline \multirow[t]{2}{*}{ No. } & \multirow[t]{2}{*}{ YEAR } & \multirow{2}{*}{$\begin{array}{c}\text { Initial } \\
\text { intervention }\end{array}$} & \multirow{2}{*}{$\begin{array}{c}\text { Total } \\
\text { intervention }\end{array}$} & \multirow{2}{*}{$\begin{array}{c}\text { Days of } \\
\text { Interventions }\end{array}$} & \multirow{2}{*}{$\begin{array}{l}\text { Total } \\
\text { days }\end{array}$} & \multirow{2}{*}{$\begin{array}{c}\begin{array}{c}\text { Next episode } \\
\text { (days away) }\end{array} \\
\end{array}$} & \multirow{2}{*}{$\begin{array}{c}\text { Type of } \\
\text { Intervention }\end{array}$} & \multicolumn{7}{|c|}{ PRE- AND POST-EVENT WINDOW } \\
\hline & & & & & & & & 2 & 5 & 10 & 20 & 30 & 40 & 60 \\
\hline \multicolumn{15}{|c|}{ Exchange rate returns } \\
\hline 1 & 1997 & -4.082 & -39.010 & 13 & 16 & 3 & SALE & WITH & WIND & WIND & & & & \\
\hline 2 & 1997 & 0.954 & 4.492 & 4 & 6 & 2 & PURCHASE & WIND & WIND & WIND & WIND & WITH & WIND & WIND \\
\hline 3 & 1997 & -4.792 & -27.843 & 10 & 14 & 36 & SALE & SMOOTH & WIND & & WITH & WITH & WIND & \\
\hline 4 & 1997 & -2.046 & -2.046 & 1 & 1 & 16 & SALE & WIND & WIND & WIND & WIND & WIND & WITH & WITH \\
\hline 5 & 1997 & 2.134 & 34.871 & 9 & 26 & 10 & PURCHASE & & & & WIND & & WIND & WIND \\
\hline 6 & 1997 & -1.161 & -7.042 & 3 & 3 & 8 & SALE & SMOOTH & SMOOTH & WIND & & & & \\
\hline 7 & 1998 & 0.989 & 4.652 & 3 & 5 & 1 & PURCHASE & WIND & WIND & WIND & WITH & WIND & WIND & WIND \\
\hline 8 & 1998 & -0.196 & -51.453 & 30 & 56 & 36 & SALE & WIND & WITH & WITH & WITH & & & \\
\hline 9 & 1998 & 2.721 & 2.721 & 1 & 1 & 24 & PURCHASE & & & & & & WITH & \\
\hline 10 & 1998 & -0.813 & -12.986 & 3 & 9 & 311 & SALE & WIND & SMOOTH & SMOOTH & SMOOTH & WIND & & WIND \\
\hline 11 & 1999 & -18.757 & -35.257 & 2 & 4 & 49 & SALE & WITH & WIND & WIND & WIND & SMOOTH & SMOOTH & SMOOTH \\
\hline 12 & 1999 & -0.899 & -6.097 & 9 & 11 & 62 & SALE & WITH & WIND & SMOOTH & & SMOOTH & SMOOTH & \\
\hline 13 & 2000 & -11.491 & -13.228 & 3 & 4 & 164 & SALE & WIND & & WIND & WIND & WIND & SMOOTH & SMOOTH \\
\hline 14 & 2000 & -8.651 & -8.651 & 1 & 1 & 225 & SALE & & WIND & WIND & WIND & WIND & WIND & WIND \\
\hline 15 & 2001 & 12.080 & 14.603 & 2 & 2 & 38 & SALE & WIND & WIND & WIND & SMOOTH & SMOOTH & & \\
\hline 16 & 2001 & 2.332 & 13.064 & 5 & 25 & 45 & SALE & WIND & WIND & SMOOTH & SMOOTH & SMOOTH & SMOOTH & SMOOTH \\
\hline 17 & 2002 & 11.513 & 31.281 & 5 & 5 & 61 & SALE & & SMOOTH & SMOOTH & WIND & WIND & WIND & SMOOTH \\
\hline 18 & 2002 & 1.169 & 28.696 & 28 & 53 & 50 & SALE & WIND & WIND & WIND & WIND & WIND & WIND & WIND \\
\hline \multicolumn{15}{|c|}{ Exchange rate volatility } \\
\hline 1 & 1997 & -4.082 & -39.010 & 13 & 16 & 3 & PURCHASE & LOW & LOW & LOW & LOW & LOW & LOW & LOW \\
\hline 2 & 1997 & 0.954 & 4.492 & 4 & 6 & 2 & SALE & LOW & LOW & HIGH & LOW & LOW & LOW & LOW \\
\hline 3 & 1997 & -4.792 & -27.843 & 10 & 14 & 36 & PURCHASE & LOW & LOW & LOW & LOW & LOW & LOW & LOW \\
\hline 4 & 1997 & -2.046 & -2.046 & 1 & 1 & 16 & PURCHASE & HIGH & HIGH & $\mathrm{HIGH}$ & HIGH & HIGH & HIGH & HIGH \\
\hline 5 & 1997 & 2.134 & 34.871 & 9 & 26 & 10 & SALE & HIGH & HIGH & HIGH & HIGH & HIGH & HIGH & HIGH \\
\hline 6 & 1997 & -1.161 & -7.042 & 3 & 3 & 8 & PURCHASE & LOW & LOW & LOW & LOW & HIGH & LOW & LOW \\
\hline 7 & 1998 & 0.989 & 4.652 & 3 & 5 & 1 & SALE & LOW & HIGH & LOW & LOW & LOW & LOW & LOW \\
\hline 8 & 1998 & -0.196 & -51.453 & 30 & 56 & 36 & PURCHASE & HIGH & HIGH & HIGH & LOW & LOW & HIGH & HIGH \\
\hline 9 & 1998 & 2.721 & 2.721 & 1 & 1 & 24 & SALE & HIGH & HIGH & HIGH & HIGH & HIGH & HIGH & HIGH \\
\hline 10 & 1998 & -0.813 & -12.986 & 3 & 9 & 311 & PURCHASE & LOW & LOW & LOW & LOW & HIGH & HIGH & HIGH \\
\hline 11 & 1999 & -18.757 & -35.257 & 2 & 4 & 49 & PURCHASE & HIGH & HIGH & HIGH & HIGH & HIGH & HIGH & HIGH \\
\hline 12 & 1999 & -0.899 & -6.097 & 9 & 11 & 62 & PURCHASE & HIGH & HIGH & HIGH & HIGH & HIGH & LOW & LOW \\
\hline 13 & 2000 & -11.491 & -13.228 & 3 & 4 & 164 & PURCHASE & LOW & LOW & HIGH & HIGH & HIGH & HIGH & HIGH \\
\hline 14 & 2000 & -8.651 & -8.651 & 1 & 1 & 225 & PURCHASE & HIGH & LOW & HIGH & HIGH & LOW & HIGH & HIGH \\
\hline 15 & 2001 & 12.080 & 14.603 & 2 & 2 & 38 & SALE & HIGH & HIGH & HIGH & HIGH & HIGH & HIGH & HIGH \\
\hline 16 & 2001 & 2.332 & 13.064 & 5 & 25 & 45 & SALE & LOW & LOW & LOW & LOW & LOW & LOW & LOW \\
\hline 17 & 2002 & 11.513 & 31.281 & 5 & 5 & 61 & SALE & LOW & LOW & LOW & HIGH & HIGH & HIGH & HIGH \\
\hline 18 & 2002 & 1.169 & 28.696 & 28 & 53 & 50 & SALE & HIGH & HIGH & LOW & LOW & LOW & LOW & LOW \\
\hline
\end{tabular}

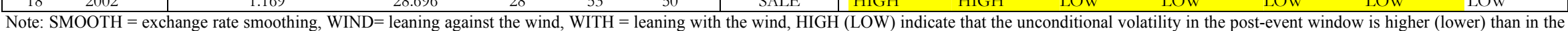
pre-event window. 
Table 4. Non-overlapping episodes, and the share of successful episodes EVENT SIZE

PRE- AND POST-EVENT WINDOW

$\begin{array}{lllllll}2 & 5 & 10 & 20 & 30 & 40 & 60\end{array}$

\begin{tabular}{|c|c|c|c|c|c|c|c|}
\hline \multicolumn{8}{|l|}{2 DAYS } \\
\hline TOTAL EPISODES & 29 & 29 & 29 & 29 & 29 & 29 & 29 \\
\hline ASSESSABLE ( $\%$ of total) & $93 \%$ & $55 \%$ & $38 \%$ & $24 \%$ & $21 \%$ & $17 \%$ & $7 \%$ \\
\hline SUCCESS (\% of assessable) & $67 \%$ & $75 \%$ & $91 \%$ & $71 \%$ & $100 \%$ & $100 \%$ & $100 \%$ \\
\hline AGAINST ( $\%$ of assessable) & $72 \%$ & $67 \%$ & $80 \%$ & $80 \%$ & $50 \%$ & $40 \%$ & $50 \%$ \\
\hline SMOOTH ( $\%$ of assessable) & $6 \%$ & $33 \%$ & $40 \%$ & $20 \%$ & $50 \%$ & $60 \%$ & $50 \%$ \\
\hline WITH ( $\%$ of assessable) & $22 \%$ & $0 \%$ & $0 \%$ & $0 \%$ & $0 \%$ & $0 \%$ & $0 \%$ \\
\hline \multicolumn{8}{|l|}{5 DAYS } \\
\hline TOTAL EPISODES & 22 & 22 & 22 & 22 & 22 & 22 & 22 \\
\hline ASSESSABLE ( $\%$ of total) & $77 \%$ & $77 \%$ & $68 \%$ & $36 \%$ & $27 \%$ & $23 \%$ & $9 \%$ \\
\hline SUCCESS (\% of assessable) & $76 \%$ & $82 \%$ & $80 \%$ & $75 \%$ & $100 \%$ & $100 \%$ & $100 \%$ \\
\hline AGAINST ( $\%$ of assessable) & $69 \%$ & $71 \%$ & $67 \%$ & $67 \%$ & $50 \%$ & $40 \%$ & $50 \%$ \\
\hline SMOOTH ( $\%$ of assessable) & $8 \%$ & $29 \%$ & $33 \%$ & $33 \%$ & $50 \%$ & $60 \%$ & $50 \%$ \\
\hline WITH (\% of assessable) & $23 \%$ & $0 \%$ & $0 \%$ & $0 \%$ & $0 \%$ & $0 \%$ & $0 \%$ \\
\hline \multicolumn{8}{|l|}{10 DAYS } \\
\hline TOTAL EPISODES & 21 & 21 & 21 & 21 & 21 & 21 & 21 \\
\hline ASSESSABLE ( $\%$ of total) & $90 \%$ & $76 \%$ & $71 \%$ & $38 \%$ & $29 \%$ & $24 \%$ & $10 \%$ \\
\hline SUCCESS (\% of assessable) & $79 \%$ & $81 \%$ & $80 \%$ & $75 \%$ & $100 \%$ & $100 \%$ & $100 \%$ \\
\hline AGAINST ( $\%$ of assessable) & $60 \%$ & $69 \%$ & $67 \%$ & $67 \%$ & $50 \%$ & $40 \%$ & $50 \%$ \\
\hline SMOOTH ( $\%$ of assessable) & $13 \%$ & $31 \%$ & $33 \%$ & $33 \%$ & $50 \%$ & $60 \%$ & $50 \%$ \\
\hline WITH ( $\%$ of assessable) & $27 \%$ & $0 \%$ & $0 \%$ & $0 \%$ & $0 \%$ & $0 \%$ & $0 \%$ \\
\hline \multicolumn{8}{|l|}{30 DAYS } \\
\hline TOTAL EPISODES & 18 & 18 & 18 & 18 & 18 & 18 & 18 \\
\hline ASSESSABLE ( $\%$ of total) & $89 \%$ & $72 \%$ & $61 \%$ & $56 \%$ & $44 \%$ & $33 \%$ & $11 \%$ \\
\hline SUCCESS (\% of assessable) & $75 \%$ & $77 \%$ & $91 \%$ & $80 \%$ & $100 \%$ & $100 \%$ & $100 \%$ \\
\hline AGAINST ( $\%$ of assessable) & $58 \%$ & $70 \%$ & $60 \%$ & $63 \%$ & $50 \%$ & $50 \%$ & $50 \%$ \\
\hline SMOOTH (\% of assessable) & $17 \%$ & $30 \%$ & $40 \%$ & $38 \%$ & $50 \%$ & $50 \%$ & $50 \%$ \\
\hline WITH (\% of assessable) & $25 \%$ & $0 \%$ & $0 \%$ & $0 \%$ & $0 \%$ & $0 \%$ & $0 \%$ \\
\hline
\end{tabular}

Table 5. Intervention episodes and unconditional exchange rate volatility EVENT SIZE PRE- AND POST-EVENT WINDOW

\begin{tabular}{|lrrrrrrr|} 
& $\mathbf{2}$ & $\mathbf{5}$ & $\mathbf{1 0}$ & $\mathbf{2 0}$ & $\mathbf{3 0}$ & $\mathbf{4 0}$ & $\mathbf{6 0}$ \\
\hline 2 DAYS & & & & & & & \\
TOTAL EPISODES & 29 & 29 & 29 & 29 & 29 & 29 & 29 \\
ASSESSABLE (\% of total) & $93 \%$ & $55 \%$ & $38 \%$ & $24 \%$ & $21 \%$ & $17 \%$ & $7 \%$ \\
$\quad$ LOW (\% of assessable) & $56 \%$ & $44 \%$ & $27 \%$ & $0 \%$ & $17 \%$ & $20 \%$ & $0 \%$ \\
$\quad$ HIGH (\% of assessable) & $44 \%$ & $56 \%$ & $73 \%$ & $100 \%$ & $83 \%$ & $80 \%$ & $100 \%$ \\
\hline 5 DAYS & & & & & & & \\
TOTAL EPISODES & 22 & 22 & 22 & 22 & 22 & 22 & 22 \\
ASSESSABLE (\% of total) & $77 \%$ & $77 \%$ & $68 \%$ & $36 \%$ & $27 \%$ & $23 \%$ & $9 \%$ \\
$\quad$ LOW (\% of assessable) & $41 \%$ & $47 \%$ & $33 \%$ & $13 \%$ & $17 \%$ & $20 \%$ & $0 \%$ \\
$\quad$ HIGH (\% of assessable) & $59 \%$ & $53 \%$ & $67 \%$ & $88 \%$ & $83 \%$ & $80 \%$ & $100 \%$ \\
\hline 10 DAYS & & & & & & & \\
TOTAL EPISODES & 21 & 21 & 21 & 21 & 21 & 21 & 21 \\
ASSESSABLE (\% of total) & $90 \%$ & $76 \%$ & $71 \%$ & $38 \%$ & $29 \%$ & $24 \%$ & $10 \%$ \\
$\quad$ LOW (\% of assessable) & $53 \%$ & $50 \%$ & $33 \%$ & $13 \%$ & $17 \%$ & $20 \%$ & $0 \%$ \\
$\quad$ HIGH (\% of assessable) & $47 \%$ & $50 \%$ & $67 \%$ & $88 \%$ & $83 \%$ & $80 \%$ & $100 \%$ \\
\hline 30 DAYS & & & & & & & \\
TOTAL EPISODES & 18 & 18 & 18 & 18 & 18 & 18 & 18 \\
ASSESSABLE (\% of total) & $89 \%$ & $72 \%$ & $61 \%$ & $56 \%$ & $44 \%$ & $33 \%$ & $11 \%$ \\
$\quad$ LOW (\% of assessable) & $50 \%$ & $46 \%$ & $36 \%$ & $30 \%$ & $38 \%$ & $33 \%$ & $0 \%$ \\
HIGH (\% of assessable) & $50 \%$ & $54 \%$ & $64 \%$ & $70 \%$ & $63 \%$ & $67 \%$ & $100 \%$ \\
\hline
\end{tabular}




\section{Econometric Investigation}

\subsection{Interventions, Exchange Rates and Volatility}

The effectiveness of foreign exchange interventions is investigated using a GARCH framework, which is admittedly well suited for such an investigation because they analyse simultaneously the mean and the conditional variance of the exchange rate series. Dominguez (1998) used a mean equation specification, in which the log-difference of the exchange rate returns $\left(\Delta e_{t}\right)$ are regressed on the intervention series $\left(I_{t}\right)$, the interest differential $\left(\Delta i_{t}\right)$ between overnight money market rates in the home economy and the foreign benchmark (Germany and the euro area) ${ }^{13}$, and dummy variables capturing day of the week effects. The conditional variance equation includes the absolute value of interventions, the interest differential and day-of-the-week dummies. We extend this approach by distinguishing not only between domestic currency sales and purchases but also between small and large interventions and one-day and longer intervention episodes. Large interventions are defined as interventions higher than the average of the interventions (in the same direction) over the whole period, and small interventions are those below the average.

$$
\begin{aligned}
& \Delta e_{t}=\phi_{1}+\phi_{21} \cdot I_{t}^{P-\text { large }}+\phi_{22} \cdot I_{t}^{P-\text { small }}+\phi_{23} \cdot I_{t}^{S-\text { large }}+\phi_{24} \cdot I_{t}^{S-\text { small }}+\phi_{3} \cdot \Delta i_{t}+\sum_{i=1}^{4} \phi_{3+i} \cdot D_{i}+\varepsilon_{t} \\
& \varepsilon_{t} \Omega_{t-1} \sim N\left(0, \sigma^{2}\right) \\
& \sigma_{t}^{2}=\psi_{1}+\psi_{21} \cdot I_{t}^{P-\text { large }}+\psi_{22} \cdot I_{t}^{P-\text { small }}+\psi_{23} \cdot I_{t}^{S-\text { large }}+\psi_{24} \cdot I_{t}^{S-\text { small }}+\psi_{3} \cdot \Delta i_{t}+\psi \cdot D_{i}+\alpha \cdot \varepsilon_{t-1}^{2}+\beta \cdot \sigma_{t-1}^{2}
\end{aligned}
$$

where $I_{t}$ takes negative (positive) values for purchases (sales) of the domestic currency. $D_{1}, D_{2}, D_{3}$ and $D_{4}$ are dummy variables that take the value of 1 on Monday, Tuesday, Wednesday and Thursday, respectively. $\varepsilon_{t-1}^{2}$ and $\sigma_{t-1}^{2}$ are the ARCH and GARCH terms. Ísberg and Pétursson (2003) suggest the use of a dummy variable, which captures long intervention episodes. The dummy takes the value of 1 if a given intervention act is preceded by intervention activity in (t-1) and (t-2). In addition to the Ísberg and Pétursson dummy, we also use a more

\footnotetext{
${ }^{13}$ Overnight money market rates are drawn from Bloomberg for the Czech economy, and from the Deutsche Bundesbank for Germany and the euro area.
} 
loosely defined dummy, which is 1 if any given intervention is preceded by intervention during one of the preceding five days, and is 0 otherwise. To correct for the endogeneity bias, which arises in the context of exchange rate returns and interventions, equations (1) and (3) are respecified with one- and two-day lagged interventions, respectively. The equations presented thus far rest on a GARCH $(1,1)$ model. In order to check for robustness to model specification and to look at possible asymmetries in the conditional variance equation, a number of alternative GARCH models are also used for the econometric investigation, and these are (a) the GARCH in mean (GARCH-M), (b) the exponential GARCH (EGARCH), (c) the threshold GARCH (TGARCH) and (d) the component GARCH (CGARCH).

\subsection{The Causal Direction between Interventions and Forex Volatility}

Although the GARCH framework provides help in identifying any relationship between official interventions on the one hand, and between changes in and the volatility of the exchange rate, on the other hand, it does not indicate the direction of causality, i.e. whether past exchange volatility initiates interventions or past interventions leads to higher volatility or whether interventions are exogenous. An interesting question to address is the causal relation between interventions and exchange rate volatility. Central banks may intervene in order to lower volatility on disorderly exchange markets. This may be especially the case during periods of market turmoil. However, during periods of relative calm, central banks may want to intervene to increase exchange rate volatility. This is because higher market uncertainty may discourage market participants to take large open positions (Edison et al., 2003).

When investigating the relationship between interventions and forex volatility, one may use either volatility measures based on the implied volatility of option prices (Bonser-Neal and Tanner (1996), Dauchy (2001), Beine et al. (2002) for the three big currency pairs and Rogers and Siklos (2003) for Canada and Australia) or volatility derived using econometric techniques, such as the GARCH framework (Dominguez, 1998, Edison et al, 2003, and Guimaraes and Karacadag, 2004). We follow the second avenue mainly because of the lack of data on currency options in the countries under study, and the conditional volatility obtained from the different GARCH models is employed. 
The issue of causality between interventions and exchange rate volatility can be addressed using pair-wise Granger causality tests. According to the concept of Granger causality, not only lagged values of koruna sales and purchases (volatility) but also past values of volatility, $V O L$, (interventions) can impact on interventions (volatility) as shown below:

$$
\begin{aligned}
& \left|I_{t}^{\text {sales }}\right|=\omega_{0}+\sum_{i=1}^{k} \omega_{i}\left|I_{t}^{\text {sales }}\right|+\sum_{i=1}^{k} \theta_{i} V O L_{t-i}+\varepsilon_{t} \\
& V O L_{t}=\omega_{0}+\sum_{i=1}^{k} \omega_{i} V O L_{t-i}+\sum_{i=1}^{k} \theta_{i}\left|I_{t}^{\text {sales }}\right|+\varepsilon_{t} \\
& \left|I_{t}^{\text {purchases }}\right|=\omega_{0}+\sum_{i=1}^{k} \omega_{i}\left|I_{t}^{\text {purchases }}\right|+\sum_{i=1}^{k} \theta_{i} V O L_{t-i}+\varepsilon_{t} \\
& V O L_{t}=\omega_{0}+\sum_{i=1}^{k} \omega_{i} V O L_{t-i}+\sum_{i=1}^{k} \theta_{i}\left|I_{t}^{\text {purchases }}\right|+\varepsilon_{t}
\end{aligned}
$$

where $k$ is the lag length. Conventional F-tests can be carried out to verify if the joint null hypothesis of $H_{0}: \theta_{1}=\theta_{2}=\ldots=\theta_{k}=0$ can be rejected, i.e. whether or not lagged values of volatility (interventions) are significant in statistical terms. If the null hypothesis is rejected, volatility (intervention) is said to Granger-cause interventions (volatility).

Given that both the intervention and the volatility series are found to be difference stationary in levels, the Granger causality tests are carried out for variables in levels.

\subsection{Estimation Results}

The estimations are carried out using interventions without lag, and with one-, two- and threeday lags for the entire period (1997:06-2002:12) and for two sub-periods. The first sub-period covers the aftermath of the currency crisis and runs from 1997:06 to 1998:05. The second subperiod from 1998:06 to 2002:12 is the period when only koruna sales took place in order to slow down or counteract the nominal appreciation. The results are reported in Tables $6 \mathrm{a}$ to $6 \mathrm{c}$.

For the whole period, the estimation results indicate that only small koruna purchases ${ }^{14}$ are correlated significantly with the exchange rate when using interventions without lag. However, the relationship is negative, and this implies that koruna purchases are linked to currency

\footnotetext{
${ }^{14}$ Large interventions are defined as interventions higher than the average of the interventions over the whole period, and small interventions are those below the average. For purchases (sales), average purchases (sales) are used. Thus, what is large is defined as compared to the average of the interventions in the same direction.
} 
depreciation rather than a nominal appreciation as we would have expected ${ }^{15}$. For interventions with a two-day lag, in addition to small koruna purchases, large koruna purchases also turn out to have a robust negative relationship with the exchange rate. At the same time, $D^{p \text {-long is }}$ significant with a negative sign, meaning that long periods of koruna go hand in hand with an appreciation of the exchange rate. Looking at the results obtained for the sub-period 1997 to 1998, the results change slightly. Only small koruna purchases without lag and large koruna purchases with a two-day lag have a statistically significant and negative relationship with the exchange rate. The dummy $D^{p-l o n g}$ becomes mostly insignificant, regardless whether using lags or not.

Coming now to koruna sales, only large koruna sales enter the estimated equations significantly and with a positive sign, and this for the lagged specification. Hence, koruna sales seem to have the expected effect on the exchange rate by leading to a depreciation. For the first sub-period, they do not appear to matter for the exchange rate for any of the specifications. Let us now turn to the second sub-period, which contains only koruna sales. The results reported in Table 6c provide strong for that small koruna sales go indeed in tandem with a currency depreciation. However, this holds true only without lags. For lagged interventions, only large koruna sales are found to be statistically significant and signed positively. The length of the intervention ( $\left.D^{s-l o n g}\right)$ does not seem to play a role. Finally, it deserves mention that the results for interventions with one day are not reported here because the former is very similar to results obtained without.

Let us now analyse the relationship between interventions and exchange rate volatility. According to the conditional variance equations reported in Tables 6a-6c, large and small koruna purchases tend to be associated with an increase in forex volatility. The dummy $D^{\text {p-long }}$ is negative if it is found to be significant, indicating that prolonged periods of koruna purchases may be linked to a fall in forex volatility. For koruna sales, longer periods of interventions are related to higher forex volatility (Table 6b). The same applies to large koruna sales (Table 6c). However, it is fair to say that these relationships are not particularly robust to different types of GARCH models and to the use of lags.

\footnotetext{
${ }^{15}$ Koruna purchases (sales) are denoted by negative (positive) figures. As the exchange rate is defined in foreign currency terms (a decrease (increase) indicates an appreciation (depreciation)), a positive relationship between koruna purchases (sales) and the exchange rate indicates that purchases (sales) cause the exchange rate to appreciation (depreciation). A negative relationship implies that purchases (sales) lead to a currency depreciation (appreciation).
} 
Notwithstanding the slim evidence in favour of a robust relationship positive between interventions and exchange rate volatility, i.e. forex exchange interventions are linked to an increase in forex volatility, pair-wise Granger causality tests are carried out for koruna sales and purchases in order to determine the direction of causality. As shown in Table 4, exchange rate volatility triggers koruna purchases at lag length higher than 10. At the same time, for lags below 10, an opposite causation runs from koruna purchases to forex volatility. The same causal relationship can be established for koruna sales. Hence, increased forex volatility causes the central bank to purchase koruna, which in turn leads to a rise in forex volatility. For koruna sales, foreign exchange interventions simply lead to higher forex volatility.

Table 6a. Estimation Results, 1997 to 2002

\begin{tabular}{|c|c|c|c|c|c|c|c|c|c|c|}
\hline & \multicolumn{5}{|c|}{$I_{t}$} & \multicolumn{5}{|c|}{$I_{t-2}$} \\
\hline & GARCH & $\begin{array}{l}\text { GARCH- } \\
\text { in-Mean }\end{array}$ & EGARCH & TGARCH & CGARCH & GARCH & $\begin{array}{l}\text { GARCH- } \\
\text { in-Mean }\end{array}$ & EGARCH & TGARCH & CGARCH \\
\hline \multicolumn{11}{|c|}{ MEAN EQUATION } \\
\hline$I^{P-l \arg e}$ & $-0.0006^{*}$ & $-0.0006^{*}$ & -0.0006 & -0.0005 & $-0.0008^{* * *}$ & $-0.0018^{* * *}$ & $-0.0021 * * *$ & $-0.0021 * * *$ & $-0.0018^{* * *}$ & $-0.0018^{* * *}$ \\
\hline$I^{P-\text { small }}$ & $-0.0029 * *$ & $-0.0028^{* * *}$ & $-0.0027 * *$ & $-0.0023^{* * *}$ & $-0.0022^{* * *}$ & -0.0028 & $-0.0038^{* *}$ & $-0.0038^{* *}$ & -0.0028 & -0.0017 \\
\hline$S-l$ arge & 0.0000 & 0.0000 & 0.0002 & 0.0001 & 0.0001 & $0.0005^{* *}$ & $0.0006^{* * *}$ & $0.0009 * * *$ & $0.0006^{* *}$ & $0.0004^{*}$ \\
\hline$I^{S-\text { small }}$ & 0.0005 & 0.0005 & 0.0007 & 0.0004 & 0.0001 & 0.0009 & 0.0006 & 0.0003 & 0.0009 & 0.0004 \\
\hline$D^{P-l o n g}$ & -0.0022 & $-0.0024^{*}$ & -0.0009 & -0.0010 & $-0.0019 *$ & $-0.0044^{*}$ & $-0.0063^{* * *}$ & $-0.0069 * * *$ & $-0.0044^{*}$ & -0.0026 \\
\hline$D^{S-l o n g}$ & -0.0011 & -0.0010 & $-0.0013^{*}$ & $-0.0016^{* *}$ & -0.0012 & -0.0011 & -0.0004 & -0.0002 & -0.0011 & 0.0001 \\
\hline$\Delta i$ & 0.0000 & 0.0000 & 0.0000 & 0.0000 & 0.0000 & 0.0000 & 0.0000 & 0.0000 & 0.0000 & 0.0000 \\
\hline \multicolumn{11}{|c|}{ VARIANCE EQUATION } \\
\hline$I^{P-l \operatorname{larg} e}$ & $-1.2^{\mathrm{E}}-05^{* * *}$ & $-1.2^{\mathrm{E}}-05^{* *}$ & $-0.2613^{* * *}$ & 0.0000 & $\begin{array}{l}0.0000 \\
0.0000\end{array}$ & 0.0000 & 0.0000 & -0.0515 & 0.0000 & $\begin{array}{l}0.0000 \\
0.0000\end{array}$ \\
\hline$I^{P-\text { small }}$ & $-3.1 \mathrm{E}_{-} 05^{* * *}$ & $-3.2^{\mathrm{E}-05^{* * *}}$ & $-0.7280^{* * *}$ & 0.0000 & $\begin{array}{l}0.0000 \\
0.0000\end{array}$ & 0.0000 & 0.0000 & -0.2636 & 0.0000 & $\begin{array}{l}0.0000 \\
0.0000\end{array}$ \\
\hline$I^{S-l \arg e}$ & 0.0000 & 0.0000 & $0.1171 * *$ & 0.0000 & $\begin{array}{l}0.0000 \\
0.0000\end{array}$ & 0.0000 & $2.4^{\mathrm{E}}-06^{*}$ & 0.0532 & 0.0000 & $\begin{array}{l}0.0000 \\
0.0000\end{array}$ \\
\hline$I^{S-\text { small }}$ & 0.0000 & 0.0000 & 0.1224 & $-3.3^{\mathrm{E}}-06^{* * *}$ & $\begin{array}{l}0.0000 \\
0.0000\end{array}$ & 0.0000 & $-4.2^{\mathrm{E}}-06^{* * *}$ & -0.0775 & 0.0000 & $\begin{array}{l}0.0000 \\
0.0000\end{array}$ \\
\hline$D^{P-l o n g}$ & $-5.5^{\mathrm{E}}-05^{* * *}$ & $-5.7^{\mathrm{E}}-05^{* * *}$ & $-1.1512^{* *}$ & 0.0000 & $\begin{array}{l}0.0000 \\
0.0000\end{array}$ & 0.0000 & 0.0000 & -0.4144 & 0.0000 & $\begin{array}{l}0.0000 \\
0.0000\end{array}$ \\
\hline$D^{S-l o n g}$ & 0.0000 & 0.0000 & -0.1621 & 0.0000 & $\begin{array}{l}0.0000 \\
0.0000\end{array}$ & 0.0000 & 0.0000 & 0.0232 & 0.0000 & $\begin{array}{l}0.0000 \\
0.0000\end{array}$ \\
\hline$\Delta i$ & $1.6^{\mathrm{E}}-07^{* * *}$ & $1.6^{\mathrm{E}}-07^{* *}$ & 0.0055 & $-2.2^{\mathrm{E}}-07^{* * *}$ & $\begin{array}{l}0.0000 \\
0.0000\end{array}$ & 0.0000 & $3.1 \mathrm{E}-07 * * *$ & $0.0059^{*}$ & 0.0000 & $\begin{array}{l}1.5^{\mathrm{E}}-06^{* * *} \\
-1.1^{\mathrm{E}}-06^{* * *}\end{array}$ \\
\hline
\end{tabular}

Notes: $I_{t}$ and $I_{t-2}$ refer to the contemporaneous or the delayed use of interventions. $I$ is the aggregate intervention, $|I|$ is the absolute value of aggregate intervention, $\Delta i$ is the interest differential, $I^{\text {large }} I^{\text {small }}$ stand for large and small interventions, $I^{\text {purchase }}$ and $I^{\text {sales }}$ denote domestic currency purchases and sales, $I^{P-l \text { arg } e} I^{P \text {-small }} I^{S-l \text { arge }}$ and $I^{\text {S-small }}$ refer to large and small domestic currency purchases (P) and sales (S), respectively. $D^{P-l o n g}$ and $D^{S-l o n g}$ are dummy variables capturing prolonged intervention periods of domestic currency purchases (P) and sales (S). For the variance equation, two figures are reported for CGARCH. The upper one refers to the long-term variance equations, and the one situated below is obtained from the short-term variance equation. *, ** and *** denote statistical significance at the $10 \%, 5 \%$ and $1 \%$ level, respectively. 
Table 6b. Estimation Results, 1997 to 1998

\begin{tabular}{|c|c|c|c|c|c|c|c|c|c|c|}
\hline & \multicolumn{5}{|c|}{$I_{t}$} & \multicolumn{5}{|c|}{$I_{t-2}$} \\
\hline & GARCH & $\begin{array}{l}\text { GARCH- } \\
\text { in-Mean }\end{array}$ & EGARCH & TGARCH & CGARCH & GARCH & $\begin{array}{l}\text { GARCH- } \\
\text { in-Mean }\end{array}$ & EGARCH & TGARCH & CGARCH \\
\hline \multicolumn{11}{|c|}{ MEAN EQUATION } \\
\hline$I^{P-l \arg e}$ & -0.0006 & -0.0003 & -0.0005 & $-0.0008^{*}$ & -0.0004 & $-0.0014 * *$ & $-0.0018^{* * *}$ & $-0.0011^{*}$ & $-0.0014 * *$ & $-0.0016^{* * *}$ \\
\hline$I^{P-\text { small }}$ & $-0.0024^{* * *}$ & -0.0012 & $-0.0019 * * *$ & $-0.0032^{* * *}$ & $-0.0021 * * *$ & -0.0022 & $-0.0037 *$ & -0.0012 & -0.0021 & $-0.0031 * *$ \\
\hline$I^{S-l \text { arg } e}$ & -0.0001 & -0.0003 & 0.0001 & -0.0001 & -0.0002 & 0.0000 & 0.0000 & -0.0002 & 0.0001 & 0.0000 \\
\hline IS-small & 0.0000 & -0.0007 & 0.0000 & 0.0000 & -0.0003 & 0.0002 & 0.0001 & -0.0001 & 0.0002 & 0.0000 \\
\hline$D^{P-l o n g}$ & -0.0009 & 0.0000 & -0.0026 & -0.0007 & -0.0013 & -0.0023 & $-0.0045^{*}$ & -0.0015 & -0.0027 & $-0.0036^{*}$ \\
\hline$D^{S-l o n g}$ & $-0.0020^{* *}$ & -0.0015 & $-0.0019 *$ & $-0.0022 * * *$ & $-0.0019 * *$ & -0.0005 & -0.0006 & 0.0006 & -0.0005 & -0.0003 \\
\hline$\Delta i$ & 0.0000 & -0.0001 & -0.0002 & 0.0001 & -0.0001 & 0.0000 & 0.0000 & -0.0001 & 0.0000 & -0.0001 \\
\hline \multicolumn{11}{|c|}{ VARIANCE EQUATION } \\
\hline$I^{P-l \arg e}$ & 0.0000 & 0.0000 & -0.0408 & 0.0000 & $\begin{array}{l}0.0000 \\
0.0000\end{array}$ & $-5.8^{\mathrm{E}}-06^{* * *}$ & 0.0000 & -0.1360 & $-9.4^{\mathrm{E}}-06^{* * *}$ & $\begin{array}{l}2.9 \mathrm{E}-06^{* * *} \\
-7.6^{\mathrm{E}}-06^{* *}\end{array}$ \\
\hline$I^{P-\text { small }}$ & 0.0000 & 0.0000 & $0.5043^{*}$ & 0.0000 & $\begin{array}{l}0.0000 \\
0.0000\end{array}$ & $-3.1 \mathrm{E}-05^{* * *}$ & $-2.9^{\mathrm{E}}-05^{* *}$ & -0.0209 & $-4.4 \mathrm{E}-05^{* * *}$ & $\begin{array}{l}0.0000 \\
0.0000\end{array}$ \\
\hline$I^{S-l \text { arg } e}$ & 0.0000 & 0.0000 & 0.0478 & 0.0000 & $\begin{array}{l}0.0000 \\
0.0000\end{array}$ & 0.0000 & 0.0000 & 0.1692 & 0.0000 & $\begin{array}{l}0.0000 \\
0.0000\end{array}$ \\
\hline$I^{S \text {-small }}$ & 0.0000 & 0.0000 & 0.0425 & 0.0000 & $\begin{array}{l}0.0000 \\
0.0000\end{array}$ & 0.0000 & $5.2^{\mathrm{E}-0}-06^{* * *}$ & $0.59509^{* * *}$ & 0.0000 & $\begin{array}{l}0.0000 \\
0.0000\end{array}$ \\
\hline$D^{P-l o n g}$ & 0.0000 & 0.0000 & -0.1550 & 0.0000 & $\begin{array}{l}0.0000 \\
0.0000\end{array}$ & $-4.5^{\mathrm{E}}-05^{* * *}$ & $-3.9^{\mathrm{E}}-05^{* * *}$ & -1.0084 & $-6.5^{\mathrm{E}}-05^{* * *}$ & $\begin{array}{l}0.0000 \\
0.0000\end{array}$ \\
\hline$D^{S-l o n g}$ & $-7.1 \mathrm{E}-06^{* *}$ & 0.0000 & -0.4238 & $-5.8^{\mathrm{E}-06^{* *}}$ & $\begin{array}{l}0.0000 \\
0.0000\end{array}$ & $-1.1 \mathrm{E}-05^{* * *}$ & $-1.0^{\mathrm{E}}-05^{* * *}$ & $-1.4034 * * *$ & $-9.7 \mathrm{E}_{-}-06^{* *}$ & $\begin{array}{l}0.0000 \\
0.0000\end{array}$ \\
\hline$\Delta i$ & $-2.9^{\mathrm{E}}-07^{* * *}$ & 0.0000 & -0.0301 & $-1.8^{\mathrm{E}}-07^{* * *}$ & $\begin{array}{l}0.0000 \\
0.0000\end{array}$ & 0.0000 & 0.0000 & -0.0431 & $2.3^{\mathrm{E}}-07 * * *$ & $\begin{array}{l}0.0000 \\
0.0000\end{array}$ \\
\hline
\end{tabular}

Notes: as for Table 3a

Table 6c. Estimation Results, 1999 to 2002

\begin{tabular}{|c|c|c|c|c|c|c|c|c|c|c|}
\hline & \multicolumn{5}{|c|}{$I_{t}$} & \multicolumn{5}{|c|}{$I_{t-2}$} \\
\hline & GARCH & $\begin{array}{l}\text { GARCH- } \\
\text { in-Mean }\end{array}$ & EGARCH & TGARCH & CGARCH & GARCH & $\begin{array}{l}\text { GARCH- } \\
\text { in-Mean }\end{array}$ & EGARCH & TGARCH & CGARCH \\
\hline \multicolumn{11}{|c|}{ MEAN EQUATION } \\
\hline$I^{S-l \text { arg e }}$ & 0.0004 & 0.0003 & 0.0005 & 0.0004 & 0.0001 & $0.0006^{* *}$ & 0.0004 & $0.0009^{* * *}$ & $0.0007^{*}$ & $0.0006^{* *}$ \\
\hline$I^{S-\text { small }}$ & $0.0022 * *$ & $0.0022^{* *}$ & $0.0019 *$ & $0.0023^{* *}$ & 0.0014 & $0.0017^{* *}$ & 0.0009 & 0.0006 & $0.0020^{*}$ & $0.0017 * * *$ \\
\hline$D^{S-l o n g}$ & -0.0010 & -0.0011 & -0.0011 & -0.0012 & -0.0006 & -0.0010 & -0.0004 & 0.0006 & -0.0010 & 0.0001 \\
\hline$\Delta i$ & -0.0001 & -0.0001 & -0.0001 & -0.0001 & -0.0001 & -0.0002 & 0.0001 & -0.0001 & 0.0000 & -0.0001 \\
\hline \multicolumn{11}{|c|}{ VARIANCE EQUATION } \\
\hline$I^{S-l \text { arg } e}$ & 0.0000 & $1.1^{\mathrm{E}}-05^{*}$ & $0.1811^{* * *}$ & $9.4^{\mathrm{E}}-06^{*}$ & $\begin{array}{l}0.0000 \\
0.0000\end{array}$ & 0.0000 & 0.0000 & $0.1582^{* * *}$ & 0.0000 & $\begin{array}{l}0.0000 \\
0.0000\end{array}$ \\
\hline$I^{S-\text { small }}$ & 0.0000 & 0.0000 & 0.2203 & 0.0000 & $\begin{array}{l}0.0000 \\
2.4^{\mathrm{E}}-05^{*}\end{array}$ & $-3.3^{\mathrm{E}}-06^{* *}$ & 0.0000 & -0.1238 & 0.0000 & $\begin{array}{l}0.0000 \\
0.0000\end{array}$ \\
\hline$D^{S-l o n g}$ & 0.0000 & 0.0000 & -0.0170 & 0.0000 & $\begin{array}{l}0.0000 \\
0.0000\end{array}$ & $3.8^{\mathrm{E}}-06^{*}$ & 0.0000 & 0.2222 & 0.0000 & $\begin{array}{l}0.0000 \\
0.0000\end{array}$ \\
\hline$\Delta i$ & $-7.0 \mathrm{E}-07 * * *$ & $-6.9 \mathrm{E}_{-} 07 * *$ & $-0.0695^{* * *}$ & $-6.6^{\mathrm{E}}-07^{* * *}$ & $\begin{array}{l}-3.5^{\mathrm{E}}-07 * * * \\
0.0000\end{array}$ & $-1.1^{\mathrm{E}}-06^{* * *}$ & 0.0000 & $-0.1085^{* * *}$ & 0.0000 & $\begin{array}{l}-8.9 \mathrm{E}_{-} 07^{* * *} \\
0.0000\end{array}$ \\
\hline
\end{tabular}

Notes: As for Table 3a 
Table 7. Pair-wise Granger Causality Tests, 1997-2002

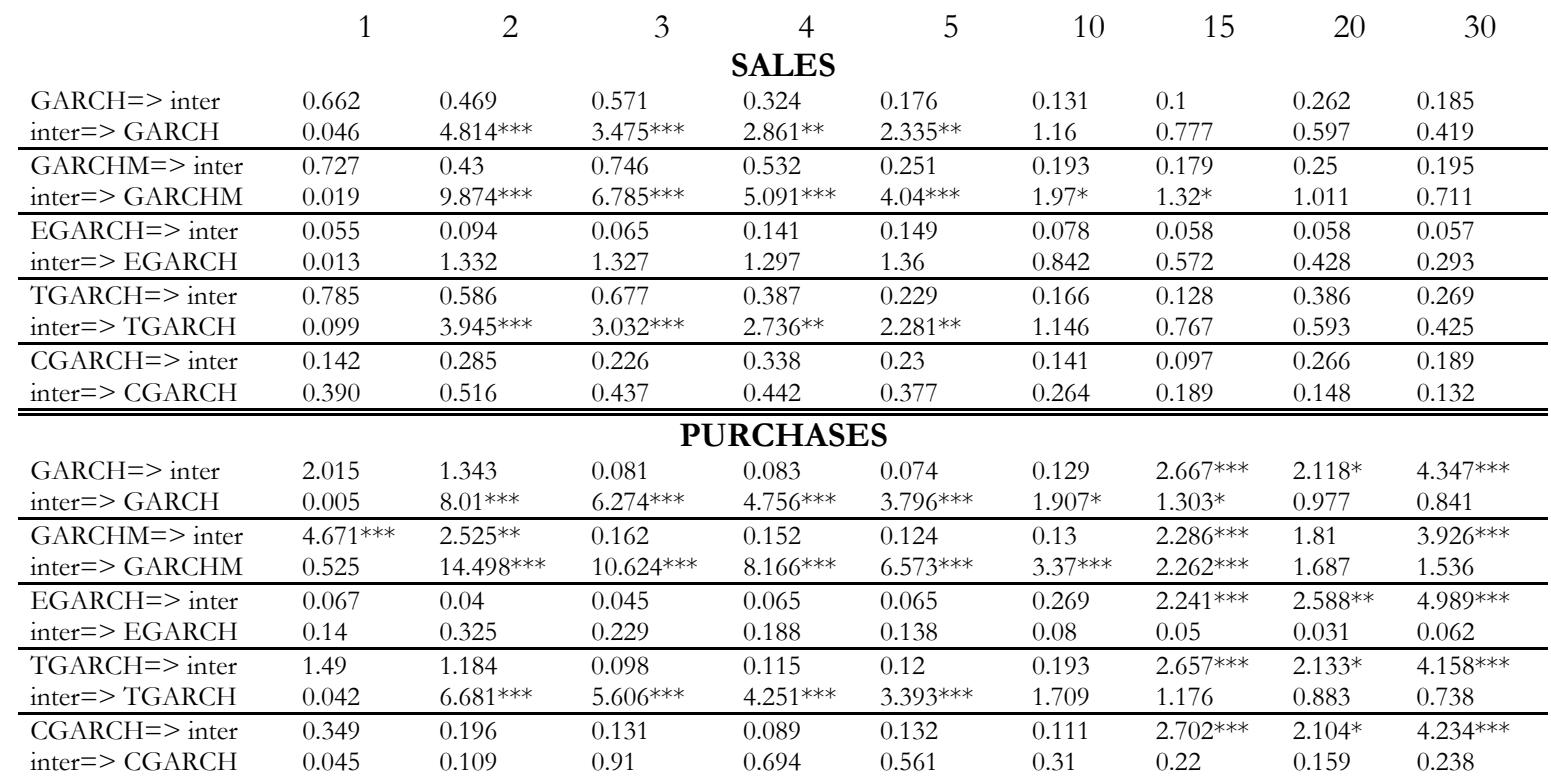

\section{Concluding Remarks}

This paper analysed the impact of foreign exchange interventions in the Czech Republic from 1997 to 2002. The event study approach showed that foreign exchange interventions of the Czech National Bank were not particularly effective in the aftermath of the currency crisis from 1997 to mid-1998. Importantly, koruna purchases are almost always very ineffective, whereas koruna sales seem to follow exchange rate smoothing or leaning against the wind in the very short run. However, from mid-1998 to 2002, interventions, exclusively koruna sales, turn out to be very powerful in reversing and smoothing the appreciation trend of the koruna up to 60 days. As far as interventions and forex volatility are concerned, although there appears to be no clear pattern in the short term, it seems that on average, interventions tend to generate more exchange rate volatility from 30 up to 60 days after the interventions took place. Looking at the individual intervention episodes shows that there are episodes for which exchange rate volatility increases or decreases depending largely upon the size of the pre- and post-event window. None the less, for a number of episodes especially in 1998 and 1999, interventions systematically cause exchange rate volatility to increase, while in 2001 and 2002, they tend to dampen forex volatility.

The GARCH estimation results broadly confirm these findings. Koruna sales appear to have no impact on the exchange rate from 1997 to 1998, whereas koruna purchases are usually associated not with an appreciation but rather with a depreciation of the exchange rate. Hence, foreign 
exchange interventions could not help to stop the depreciation of the currency. By contrast, koruna sales are found to have a strong positive relationship with the exchange rate from mid1998 to 2002. This gives strong empirical support for the view that the Czech National Bank was successful in counteracting the strong appreciation pressure on the domestic currency. Concerning interventions and forex volatility, the empirical evidence is not particularly strong. It is still fair to say that interventions tend to be related with more rather than less exchange rate volatility. For koruna purchases, higher volatility seems to ignite interventions, which in turn leads to higher volatility. This suggest that the CNB tried to calm the markets after the currency crisis, but actually failed to do so. For koruna sales, intervention activity simply yields more exchange rate volatility on the forex markets. Hence, by targeting the exchange rate of the koruna, the $\mathrm{CNB}$ generated extra noise on the markets.

It has been argued in the literature that developing and transition economies may be in a better position than industrialised countries to influence both the level and the volatility of the exchange rate via foreign exchange interventions. Overall, our results suggest that although monetary authorities may find it cumbersome, especially in times and after of market turmoil, to alter systematically the level of the exchange rate in an economy with fully liberalised capital accounts and relatively deep financial markets, acting with finesse may reap its benefits. It is, however, an open question, whether official interventions were fully sterilised in the Czech Republic. If not, this may partly explain the ability of the CNB to intervene successfully. 


\section{References}

Aguilar, J. and S. Nydahl (2000) Central bank intervention and exchange rates: The case of Sweden, Journal of International Financial Markets, Institutions and Money, 10, 303-322.

Beine, M., A. Bénassy-Quéré, E. Dauchy and R. MacDonald (2002) The Impoact of Central Bank Intervention on Exchange Rate Forecast Heterogeneity, CEPII working paper 4.

Bonser-Neal, C. and G. Tanner (1996) Central bank intervention and the volatility of foreign exchange rates: evidence from the option markets, Journal of International Money and Finance, 15, 853-877.

Brandner, P. and H. Grech (2002) Why did central banks intervene in the EMS? The post 1993 experience, Oesterreichische Nationalbank working paper 77.

Brandner, P., Grech H and H. Stix (2001) The effectiveness of central bank intervention in the EMS: The post 1993 experience, Oesterreichische Nationalbank working paper 55.

Brissimis, S. N. and D. P. Chionis (2004) Foreign exchange market intervention: implications of publicly announced and secret intervention for the euro exchange rate and its volatility, Journal of Policy Modeling, 26, 661-673.

Canales-Kriljenko, J. I. (2003) Foreign exchange intervention in developing and transition economies: Results of a survey, IMF working paper 95

Coats, W.(2000) Inflation Targeting in Transition Economies: The Case of the Czech Republic, Prague: Czech National Bank and Washington: Internation Monetary Fund, http://www.cnb.cz/pdf/mmf-final.pdf

Czech National Bank (1997, 1998, 1999, 2000, 2001, 2002) Annual Report, Prague

Dauchy, E. (2001) The Effect of Official Speeches and Central Bank Intervention Rumours on Foreign Exchange Market Forecasts, TEAM working paper, University of Paris I.

Domac, I. and A. Mendoza (2002) Is there room for forex interventions under inflation targeting framework? Evidence from Mexico and Turkey, Central Bank of the Republic of Turkey discussion paper 58.

Dominguez, K. M. (1998) Central bank intervention and exchange rate volatility, Journal of International Money and Finance, 17, 161-190

Edison, H., P. Cashin and H. Liang (2003) Foreign exchange intervention and the Australian dollar: Has it mattered? IMF working paper 99

Fatum, R. (2000) On the effectiveness of sterilised Foreign Exchange Intervention, ECB working paper 10

Fatum, R. and M. Hutchison (2003) Effectiveness of official daily foreign exchange market intervention operations in Japan, NBER working paper 9648

Guimaraes, R. and C. Karacadag (2004) The empirics of foreign exchange intervention in emerging market countries: The case of Mexico and Turkey, IMF working paper 123

Holub, T. (2004): Foreign exchange interventions under inflation targeting: The Czech experience, Czech National Bank internal research and policy note 1.

Kim, S-J., T. Kortian and J. Sheen (2000) Central bank intervention and exchange rate volatility - Australian evidence, Journal of International Financial Markets, Institutions and Money, 10, 381-405

Morana, C. and A. Beltratti (2000): Central bank interventions and exchange rates: an analysis with high frequency data, , Journal of International Financial Markets, Institutions and Money, 10, 349-362.

Ramaswamy, R. and H. Samiei (2000): The yen-dollar rate: Have interventions mattered? IMF working paper 95.

Rogers, J.M. and P.L. Siklos (2003): Foreign exchange market intervention in two small open economies: The Canadian and Australian experience, Journal of International Money and Finance, 22, 393-416.

Sarno, L. and M. P. Taylor (2001) Official intervention in the foreign exchange market: Is it effective, and, if so, how does it work? CEPR discussion paper 2690 


\section{DAVIDSON INSTITUTE WORKING PAPER SERIES - Most Recent Papers}

The entire Working Paper Series may be downloaded free of charge at: www.wdi.bus.umich.edu

CURRENT AS OF 4/08/05

\begin{tabular}{|c|c|c|}
\hline Publication & Authors & Date \\
\hline $\begin{array}{l}\text { No. 764: State Regulations, Job Search and Wage Bargaining: A Study } \\
\text { in the Economics of the Informal Sector }\end{array}$ & Maxim Bouev & Apr. 2005 \\
\hline $\begin{array}{l}\text { No. 763: The Feldstein-Horioka Puzzle Revisited: An "European- } \\
\text { Regional” Perspective }\end{array}$ & $\begin{array}{l}\text { Jérôme Hericourt and Mathilde } \\
\text { Maurel }\end{array}$ & Apr. 2005 \\
\hline $\begin{array}{l}\text { No. 762: Transatlantic Differences in Labour Markets Changes in Wage } \\
\text { and Non-Employment Structures in the 1980s and the 1990s }\end{array}$ & Patrick A. Puhani & Mar. 2005 \\
\hline $\begin{array}{l}\text { No. 761: Resolution, Recovery and Survival: The Evolution of Payment } \\
\text { Disputes in Post-Socialist Europe }\end{array}$ & William Pyle & Mar. 2005 \\
\hline $\begin{array}{l}\text { No. 760: Official Foreign Exchange Interventions in the Czech } \\
\text { Republic: Did They Matter? }\end{array}$ & Balázs Égert and Luboš Komárek & Mar. 2005 \\
\hline $\begin{array}{l}\text { No. 759: Assessing Market Expectations on Exchange Rates and } \\
\text { Inflation: A Pilot Forecasting System for Bulgaria }\end{array}$ & $\begin{array}{l}\text { Michael Berlemann, Kalina } \\
\text { Dimitrova, \& Nikolay Nenovsky }\end{array}$ & Mar. 2005 \\
\hline No. 758: Attitudes and Performance: An Analysis of Russian Workers & $\begin{array}{l}\text { Susan J. Linz and Anastasia } \\
\text { Semykina }\end{array}$ & Mar. 2005 \\
\hline $\begin{array}{l}\text { No. 757: Barter, Credit, and Welfare: A theoretical inquiry into the } \\
\text { barter phenomenon in Russia }\end{array}$ & José Noguera and Susan J. Linz & Mar. 2005 \\
\hline $\begin{array}{l}\text { No. 756: Sorting, Selection, and Transformation of the Return to } \\
\text { College Education In China }\end{array}$ & $\begin{array}{l}\text { Belton M. Fleisher, Haizheng Li, } \\
\text { Shi Li, and Xiaojun Wang }\end{array}$ & Mar. 2005 \\
\hline $\begin{array}{l}\text { No. 755: Foreign Exchange Interventions in Emerging Europe: } \\
\text { Should We Give a Damn? The Case of Croatia and Turkey }\end{array}$ & Balázs Égert and Maroje Lang & Mar. 2005 \\
\hline $\begin{array}{l}\text { No. 754: Targeting Relative Inflation Forecast as Monetary Policy } \\
\text { Framework for Adopting Euro }\end{array}$ & Lucjan T. Orlowski & Feb. 2005 \\
\hline $\begin{array}{l}\text { No. 753: Internet Entrepreneurship: Networks and Performance of } \\
\text { Internet Ventures In China }\end{array}$ & Bat Batjargal & Feb. 2005 \\
\hline $\begin{array}{l}\text { No. 752: Network Triads: Transitivity, Referral and Venture Capital } \\
\text { Decisions in China and Russia }\end{array}$ & Bat Batjargal & Feb. 2005 \\
\hline $\begin{array}{l}\text { No. 751: Software Entrepreneurship: Knowledge Networks and } \\
\text { Performance Of Software Ventures In China and Russia }\end{array}$ & Bat Batjargal & Feb. 2005 \\
\hline $\begin{array}{l}\text { No. 750: Retained State Shareholding in Chinese PLCs: Does } \\
\text { Government Ownership Reduce Corporate Value? }\end{array}$ & Lihui Tian and Saul Estrin & Feb. 2005 \\
\hline No. 749: Financial Development and Technology & Solomon Tadesse & Feb. 2005 \\
\hline No. 748: Banking Fragility and Disclosure: International Evidence & Solomon Tadesse & Feb. 2005 \\
\hline $\begin{array}{l}\text { No. 747: Consolidation, Scale Economies and Technological Change in } \\
\text { Japanese Banking }\end{array}$ & Solomon Tadesse & Feb. 2005 \\
\hline $\begin{array}{l}\text { No. 746: Trade Creation and Diversion Effects of Europe’s Regional } \\
\text { Liberalization Agreements }\end{array}$ & Yener Kandogan & Feb. 2005 \\
\hline No. 745: Quality of Institutions, Credit Markets and Bankruptcy & Christa Hainz & Feb. 2005 \\
\hline $\begin{array}{l}\text { No. 744: How Transition Paths Differ: Enterprise Performance in Russia } \\
\text { and China }\end{array}$ & Sumon Bhaumik and Saul Estrin & Jan. 2005 \\
\hline $\begin{array}{l}\text { No. 743: Inflation Targeting, Between Rhetoric and Reality. The Case } \\
\text { of Transition Economies }\end{array}$ & Daniel Daianu and Laurian Lungu & Jan. 2005 \\
\hline $\begin{array}{l}\text { No. 742: How Does Law Affect Finance? An Empirical Examination of } \\
\text { Tunneling in an Emerging Market }\end{array}$ & $\begin{array}{l}\text { Vladimir Atanasov, Conrad S. } \\
\text { Ciccotello, \& Stanley B. Gyoshev }\end{array}$ & Jan. 2005 \\
\hline $\begin{array}{l}\text { No. 741: Do Insider Trading Laws Matter? Some Preliminary } \\
\text { Comparative Evidence }\end{array}$ & Laura Nyantung Beny & Jan. 2005 \\
\hline $\begin{array}{l}\text { No. 740: Autopsy on an Empire: Understanding Mortality in Russia and } \\
\text { the Former Soviet Union }\end{array}$ & $\begin{array}{l}\text { Elizabeth Brainerd and David M. } \\
\text { Cutler }\end{array}$ & Jan. 2005 \\
\hline $\begin{array}{l}\text { No. 739: Not Separate, Not Equal: Poverty and Inequality in Post- } \\
\text { Apartheid South Africa }\end{array}$ & $\begin{array}{l}\text { Johannes G. Hoogeveen and Berk } \\
\text { Özler }\end{array}$ & Jan. 2005 \\
\hline $\begin{array}{l}\text { No. 738: The Marketing Structure in Agribusiness during the Transition } \\
\text { in Bulgaria }\end{array}$ & $\begin{array}{l}\text { Steve Murray, Yordan Staykov, } \\
\text { and Valentin Katzerov }\end{array}$ & Jan. 2005 \\
\hline No. 737: Passive Creditors & $\begin{array}{l}\text { Koen Schoors and Konstantin } \\
\text { Sonin }\end{array}$ & Jan. 2005 \\
\hline
\end{tabular}

